$\stackrel{\odot}{11}$

\title{
SPOŁECZNA PERCEPCJA ENERGETYKI JĄDROWEJ W PERSPEKTYWIE PROCESÓW TRANSFORMACJI ENERGETYCZNEJ W POLSCE
}

\begin{abstract}
Tomasz Herudziński, Społeczna percepcja energetyki jądrowej w perspektywie procesów transformacji energetycznej $w$ Polsce [Social perception of nuclear energy in the perspective of the energy transformation processes in Poland] edited by Zbigniew Drozdowicz, Sławomir Sztajer, "Człowiek i Społeczeństwo" vol. Lll: Globalne i lokalne problemy życia akademickiego [Global and local problems of academic life], Poznań 2021, pp. 251-265, Adam Mickiewicz University. ISSN 0239-3271, https://doi.org/10.14746/cis.2021.52.13.
\end{abstract}

The article analyzes the attitude of the Polish society to nuclear energy as an important energy source in the future and emphasizes the social dimension of the processes, by relating them to the sociology of energy. The attitude to nuclear energy is presented in comparison to other conventional and non-renewable energy sources, such as coal, oil or gas as well as renewable energy sources (RES) obtained from the sun, air or water. The ways of thinking and fears of the Polish society towards nuclear energy are presented in relation to the processes of energy transformation in Poland. The author indicates the main assumptions of the energy transformation and presents social ideas about the future of the energy sector in Poland. In the empirical dimension, the article concerns the sphere of social awareness and uses the results of surveys conducted by the Public Opinion Research Center (CBOS) in the period from 1987 to 2021.

Keywords: energy transformation, climate policy, nuclear energy, sociology of energy, energy poverty, social awareness

Tomasz Herudziński, Katedra Socjologii, Instytut Nauk Socjologicznych i Pedagogiki SGGW wWarszawie, ul. Nowoursynowska 166, 02-787 Warszawa, e-mail: tomasz_herudzinski@sggw.edu.pl, ORCID: https://orcid.org/0000-0002-4102-2957. 


\section{Wprowadzenie}

Przedstawiając stosunek społeczeństwa polskiego do energetyki jądrowej, umieszczono go w kontekście fundamentalnych zmian całego systemu energetycznego w Polsce. Zaplanowano je jako efekt przyjętej przez całą Unię Europejską polityki klimatycznej. W przypadku Polski zmiany te oznaczają całościową przebudowę systemu energetycznego i określane są mianem transformacji energetycznej. Jednocześnie zakłada się, że procesy te mają nie tylko wymiar gospodarczy, ale także społeczny i kulturowy. Z tego powodu, analizując badania opinii na temat zachodzących zmian, wskazano na socjologię energetyki jako subdyscyplinę wyznaczającą perspektywę poznawczą. W artykule sposoby myślenia Polaków na temat energetyki jądrowej zostały umieszczone w szerszym kontekście, porównano je do innych źródeł energii oraz odniesiono do całego planowanego procesu transformacji energetycznej.

Ważnym elementem analizy świadomości społecznej - opinii na temat transformacji energetycznej, źródeł energii, a w szczególności energetyki jądrowej - jest jej odniesienie do wizji, która określa rolę i znaczenie źródeł energii (w tym jądrowej) w przyszłości, jakie przypisują im Polacy. Pozwala to odnieść rządowe plany do myślenia społeczeństwa polskiego o transformacji energetycznej i energetyce jądrowej. Dodatkowo, opisując transformację energetyczną Polski z perspektywy społecznej percepcji procesów wchodzących w jej skład, zwraca się uwagę na zjawisko ubóstwa energetycznego jako istotny problem społeczny. Dobrym przykładem analizy energetyki jądrowej w perspektywie sfery publicznej i komunikacji społecznej w Polsce jest artykuł Aleksandry Wagner, Tiffany Grobelski i Marcina Harembskiego (2016). Autorzy, odnosząc się do typów idealnych sfery publicznej współczesnych demokracji, stwierdzają dominację typu liberalnego. Ich zdaniem wspierany jest on przez media głównego nurtu oraz elity gospodarcze i polityczne. Jednocześnie wskazuje się tu na słabość inicjatyw i ruchów oddolnych, które w znikomym stopniu odzwierciedlają się w medialnym dyskursie publicznym. Artykuł w odniesieniu do badań polityki energetycznej zwraca uwagę na istotną rolę ,integracyjnego spojrzenia na politykę energetyczną jako kwestię zarządzania publicznego" (Wagner, Grobelski i Harembski, 2016). 


\section{Społeczny wymiar energetyki - odniesienia teoretyczne i problematyka}

Obszar badań wyznaczony przez problematykę energetyczną obejmuje nie tylko wymiar techniczny, z którym zapewne kojarzony jest najczęściej, ale także wymiar społeczny. To właśnie ten drugi wymiar stara się zagospodarować socjologia energii (Misiak i Łucki, 2010). Punktem wyjścia jest tu stwierdzenie, że energia jest dobrem społecznym. Ostatecznie to społeczeństwo jest odbiorcą energii, jego członkowie decydują o jej popycie, zużyciu i konkretnym wykorzystaniu. Dodatkowo strategie rozwoju energetycznego budowane są przez polityków, którzy w systemach demokratycznych muszą uwzględniać interesy społeczeństwa jako całości i konkretnych społeczności, a w relacjach społecznych zachodzących pomiędzy kilkoma podmiotami zaistnieć może całe spektrum procesów społecznych, np. konflikty. Innymi słowy, kwestie energetyczne można i należy analizować w perspektywie relacji społecznych i nie bez racji mówi się o potrzebie wyodrębnienia socjologii energii.

Socjologia energii jako subdyscyplina jest związana z socjologią środowiska i zasadza się na zasadniczym dla tej drugiej założeniu, najogólniej przyjmującym, że zmienne środowiskowe powinny być traktowane jako wyjaśniające w analizach dotyczących rzeczywistości społecznej. To założenie podkreślają np. prace: Dunlop i Catton, 1979; Matczak, 2000; Trempała, 2016. Na szczególną zaś uwagę zasługuje praca Władysława Misiaka i Zbigniewa Łuckiego Energetyka a społeczeństwo. Aspekty socjologiczne (2010). Autorzy przedstawiają tam m.in. problemy współczesnej energetyki, rozważając je w kontekście politycznym, społecznym i kulturowym, a także zwracając uwagę na procesy zmian dotyczących najszerszego jej wymiaru kulturowego. Podkreślają różnice pomiędzy różnymi rodzajami systemów i kultur energetycznych, wskazują na nowe źródła i techniki energetyczne, akcentują aspekt zmiany kultury energetycznej. W dalszej kolejności, odnosząc się do wymiaru makroteoretycznego transformacji energetycznej Polski, należy przywołać koncepcję zrównoważonego rozwoju. Wskazuje się tu na negatywny wpływ energetyki konwencjonalnej i zmianę tego sektora poprzez wdrożenie odpowiedniej polityki klimatycznej, która zapewni dalszy rozwój społeczno-gospodarczy z jednoczesnym zmniejszeniem, czy wręcz wyeliminowaniem negatywnego wpływu środowiskowego. Zmiana ta ma się opierać 
na ograniczeniu stosowania paliw kopalnych i większym wykorzystaniu odnawialnych źródeł energii, przy jednoczesnym lepszym, bardziej racjonalnym wykorzystywaniu zasobów energetycznych. Ponadto warto zauważyć, że zmiany społeczne, ale również funkcjonowanie i rozwój, zwłaszcza taki, który wpisany jest w politykę rozwoju zrównoważonego, bardzo często związany jest z koncepcją zmian w sferze energetycznej. Transformacja energetyczna, która wchodzi w skład pakietu politycznego określanego jako Zielony Ład, to - „zielona gospodarka, zielony wzrost i zazielenienie jako koncepcje wdrożeń do gospodarki w celu zachowania ochrony środowiska, bioróżnorodności i przeciwdziałania zmianom klimatu. Koncepcje te wdrażane w Unii Europejskiej przyjęły nazwę Europejskiego Zielonego Ładu. Wszystkie zielone koncepcje powiązane są z paradygmatem zrównoważonego rozwoju i w opracowanych strategiach stają się formami jego realizacji” (Adamowicz, 2021). Energetykę w centrum zmiany społecznej stawia również Anthony Giddens, twierdząc, że położenie nacisku na odnawialne źródła energii oraz rezygnacja z dotychczasowych sposobów jej produkcji i wykorzystania stanie się podstawą wygenerowania nowej formy społeczeństwa, całkowicie odmiennej od dotychczas istniejącej (Giddens, 2010).

Ważnym aspektem społecznego wymiaru energetyki są konkretne problemy związane z procesami transformacji energetycznej. Przykładem jest tu zagadnienie rozmieszczenia elektrowni jądrowych na terenie kraju. Warto przywołać analizę autorstwa Katarzyny Zawalińskej, Jouko Kinnunena, Piotra Gradziuka i Doroty Celińskiej-Janowicz (2020), uwzględniającą najbardziej prawdopodobne lokalizacje z wykorzystaniem rekurencyjnego dynamicznego modelu obliczania równowagi ogólnej. Autorzy, biorąc pod uwagę zarówno specyfikę gospodarek poszczególnych regionów, jak i efekty aglomeracji, wskazują na konkretną lokalizację, najlepszą z perspektywy fazy eksploatacji. Wyraźnie wskazują, że w pozostałych trzech lokalizacjach należy się spodziewać niekorzystnych zmian gospodarczych zwanych „chorobą holenderską”, wcześniej opisywaną na przykładach regionów charakteryzujących się intensywną eksploatacją kopalin. Innym wymiarem tej problematyki są protesty społeczne przeciw inwestycjom energetycznym - budowie elektrowni atomowych. Najczęściej są to protesty ze strony społeczności lokalnych. Jak twierdzą Misiak i Łucki (2010): „Protesty tego typu są cennym, aczkolwiek dokuczliwym dla inwestorów, wkładem społeczeństwa w rozwój energetyki. Jeśli władze i inwestorzy zaniedbają problem pozyskania akceptacji społecznej dla swoich przedsięwzięć, społeczeństwu pozostaje jedynie dochodzenie swych praw i racji protestami, co oczywiście nie oznacza, że protesty te nie są niekiedy swoistą patologią”. 
W literaturze przedmiotu mówi się o tzw. syndromie NIMBY (ang. Not in my backyard) - chodzi tu o uniemożliwienie realizacji inwestycji energetycznej, jaką jest budowa elektrowni atomowej, w wyniku protestów społecznych mieszkańców terenów, na których planowane są inwestycje. Fundamentalną przyczyną tego zjawiska jest konflikt występujący pomiędzy interesem wspólnym społeczeństwa a interesem społeczności lokalnej. Występują tu z jednej strony korzyści z inwestycji dla całego społeczeństwa, ale jednocześnie niedogodności dla mieszkańców terenów sąsiadujących z inwestycją. Nie musi być to budowa elektrowni atomowej, gdyż analogiczna sytuacja dotyczy takich inwestycji jak wysypisko śmieci czy oczyszczalnia ścieków. W obliczu trudności dotyczących efektywności narzędzi w rodzaju sondaży publicznych czy referendów protesty społeczne są postrzegane jako skuteczne narzędzie wpływu społeczeństwa obywatelskiego na inwestycje energetyczne (Misiak i Łucki, 2010).

Omawiając energetykę jądrową w perspektywie bezpieczeństwa energetycznego, należy wspomnieć, od czego zależy popularność tego źródła energii na konwencjonalnym rynku energetycznym. Występuje tu wyraźny wpływ czynników politycznych, takich jak konflikty czy wojny, czego najlepszym przykładem jest konflikt zaistniały między Rosją a Ukrainą, który podważając bezpieczeństwo dostaw gazu, skierował opinię publiczną na tematykę elektrowni jądrowych. Warto podkreślić, że w toczącej się wówczas debacie publicznej akcentowano kwestie bezpieczeństwa także w kontekście reaktorów w Czarnobylu czy Fukushimie. Istotne jest, że bezpieczeństwo energetyczne stało się ważnym składnikiem polityki bezpieczeństwa realizowanej przez państwa członkowskie i Unię Europejską (Zajączkowska, 2016). Transformacja energetyczna kraju powinna uwzględniać wymiar bezpieczeństwa, co oznacza też umożliwienie odbiorcom indywidualnym i zakładom produkcyjnym dostępu do energii, który nie tylko będzie się charakteryzował stałością, ale i akceptowalnymi społecznie cenami. Dodatkowo bezpieczeństwo energetyczne zgodnie z zasadą zrównoważonego rozwoju powinno zapewniać taki sposób produkcji energii elektrycznej, który będzie w jak najmniejszym stopniu negatywnie wpływał na środowisko, a jednocześnie będzie bezpieczny dla zdrowia obywateli, pozytywnie wpływając na jakość ich życia. Przy tak rozumianej transformacji energetycznej kładzie się szczególny nacisk na jakość energii (Popkiewicz, 2016). Biorąc pod uwagę zarówno rosnące potrzeby energetyczne, wymagania środowiskowe, jak i jakość życia, szczególnie istotna z perspektywy transformacji energetycznej jest kwestia ekonomiczna (Olkuski, 2018), w tym zaś wymiarze zjawisko ubóstwa energetycznego. 
Zjawisko ubóstwa energetycznego jest stosunkowo nowe i nadal wiąże się z problemami definicyjnymi. Mimo tych trudności warto zwrócić uwagę za Dominikiem Owczarkiem i Agatą Miazgą, że jest to zjawisko polegające na „doświadczaniu trudności w zaspokajaniu podstawowych potrzeb energetycznych za rozsądną cenę, na które składa się utrzymanie adekwatnego standardu ciepła i zaopatrzenie w pozostałe rodzaje energii służące zaspokojeniu w adekwatny sposób podstawowych potrzeb funkcjonowania biologicznego i społecznego członków gospodarstwa domowego" (Owczarek i Miazga, 2015: 5). Na podkreślenie zasługuje fakt, że zjawisko ubóstwa energetycznego, choć związane z kwestiami finansowymi, nie jest tożsame z ubóstwem ekonomicznym. Jednocześnie zamożność społeczeństwa jest czynnikiem związanym z jego występowaniem. O różnicach pomiędzy poszczególnymi społeczeństwami dobitnie świadczy fakt korygowania zakresu progu wydatków przeznaczanych na energię w gospodarstwach rodzinnych w Polsce i określających zasięg ubóstwa energetycznego. Brytyjski próg 10\% dochodów okazał się nieodpowiedni dla Polski, ponieważ kwalifikowało to $44 \%$ społeczeństwa do kategorii ubogich energetycznie. Przy jego wykorzystaniu zdecydowanie zbyt liczna grupa gospodarstw domowych musiałaby być uznana za ubogie energetycznie. Przyjmując, że w Polsce występują „średnio wyższe wydatki energetyczne niż w Wielkiej Brytanii”, już na wstępie badań skali ubóstwa energetycznego w Polsce przyjęto próg 13-procentowy, jako bardziej odpowiadający krajowej specyfice (Owczarek i Miazga, 2015). Zgodnie z tym kryterium ubóstwo energetyczne w 2013 r. dotyczyło 32,4\% społeczeństwa polskiego (Herudziński, Boguszewski, Owczarek i Bondyra, 2019).

Miara wykorzystywana do określania skali ubóstwa przy użyciu określonego progu wydatków na energię bez względu na jego wartość 10\% czy 13\% okazała się „,nieadekwatna do struktury koszyka wydatków gospodarstw domowych w Polsce” (Herudziński i in., 2019: 57). Za najbardziej odpowiadającą polskim warunkom uważa się miarę relatywną określaną mianem „Wysokie koszty - niski dochód” (WKND). Przyjmuje się tu, że gospodarstwo domowe jest ubogie energetycznie, jeżeli wydatki na energię są wyższe niż mediana wydatków w populacji, a dochód gospodarstwa jest niższy niż 60\% mediany dochodów w populacji. Przy zastosowaniu takiego podejścia Instytut Badań Strukturalnych odnotowuje spadek ubóstwa energetycznego w Polsce z 14,4\% w 2012 do 13,7\% w 2014 i 12,2\% w 2016 r. Uwzględniając różnice zasad pomiaru ubóstwa energetycznego, w celach porównawczych wykorzystywane są odmienne dane (Swacha i Novikova, 2019). Analizy państw europejskich stosują takie odmienne podejścia. Charakteryzując zjawisko ubóstwa energetycznego z tej perspektywy, warto 
zwrócić uwagę na badania trzydziestu trzech państw, w których wykorzystano dwa wskaźniki: (1) utrzymanie ciepła, czyli deklarowany „dyskomfort cieplny” - „niezdolność do utrzymania w domu odpowiedniej temperatury”, oraz (2) zaległości w rachunkach, czyli „zgłoszenie przez gospodarstwo domowe niezdolności do płacenia rachunków za energię w ciągu ostatnich 12 miesięcy” (Swacha i Novikova, 2019: 147). Jednocześnie warto odnotować, że pojęcie „dyskomfortu cieplnego” nie odnosi się jedynie do braku możliwości ogrzania mieszkania w czasie zimy, ale również utrzymania odpowiedniej temperatury w okresie upałów. Wyniki wskazały, że wśród państw o wysokim wskaźniku (ponad 20\% wskazań) „dyskomfortu cieplnego” większość stanowiły państwa Europy Południowej: Bułgaria (39,2\%), Grecja (29,1\%), Cypr (24,3\%), Macedonia (25,7\%), Portugalia (22,5\%), a także Litwa (29,3\%). Wśród „zalegających z opłatami” przodują Grecy (42,2\%), Macedończycy (41\%), Serbowie (34,8\%), Turcy (33,2\%), Bułgarzy (31,7\%) oraz Chorwaci (25,3\%). Polacy w odniesieniu do obu wskaźników plasują się w środku zestawienia. Na trzydzieści trzy kraje Polska zajęła piętnastą pozycję w odniesieniu do „dyskomfortu cieplnego” i czternastą wśród „zalegających z opłatami” (Swacha i Novikova, 2019: 148-149).

Zagadnienie ubóstwa energetycznego w perspektywie planowanych w Polsce zmian oraz społecznego ich odbioru w znacznym stopniu związane jest z ogólnym przekonaniem dotyczącym opłacalności inwestycji w energię odnawialną. Dobrym przykładem jest artykuł, którego autorzy tytułowym problemem uczynili wzrost cen energii elektrycznej, pytając dalej, czy może być on „siłą napędową transformacji energetycznej w krajach, w których sektor energetyczny jest uzależniony od węgla” (Żuk i Żuk, 2021: 2). Zaprezentowane ogólnopolskie badania obejmujące przedstawicieli firm decydujących o inwestycjach w energetykę odnawialną wskazują, że istotną rolę odgrywa tu struktura własnościowa przedsiębiorstwa - w większym stopniu zainteresowane nią są firmy duże i reprezentujące sektor publiczny.

\section{Stosunek społeczeństwa do energetyki jądrowej}

Historycznie pierwszą próbę wygenerowania energii elektrycznej przy wykorzystaniu reaktora atomowego zakończono sukcesem w 1948 r. w Tennessee (Stany Zjednoczone), czego dowodem była świecąca dzięki tej energii żarówka. Analogiczne działania miały miejsce w roku 1954 w okolicach Moskwy (ZSRR) - tam elektrownia jądrowa po raz pierwszy zasiliła sieć energetyczną. Następna tego typu jednostka powstała w 1956 r. 
w Anglii (elektrownia jądrowa Calder Hall), a rok później ponownie w USA (Jezierski, 2014). Energetyka jądrowa zajmuje szczególny obszar społecznej świadomości energetycznej. Wynika to z faktu, że od początku budzi silne emocje społeczne, będąc przedmiotem żywej dyskusji publicznej oraz licznych konfliktów. Ponieważ pierwszy reaktor jądrowy uruchomiony został w Stanach Zjednoczonych już w 1957 r., warto na przykładzie społeczeństwa amerykańskiego prześledzić zmiany sposobów myślenia na temat energii atomowej. Najogólniej można stwierdzić, że jest ono odzwierciedleniem dynamicznych, a nawet burzliwych zmian opinii i postaw społecznych wobec tego źródła energii. Pierwotnie upatrywano w energetyce jądrowej wyłącznie zalet, traktując ten sposób pozyskiwania energii nie tylko jako korzystny czynnik rozwoju gospodarczego kraju, dobrze rokujący na przyszłość, ale przede wszystkim jako osiągnięcie cywilizacyjne. Po awarii w 1979 r. w Three Miles Island - cywilnej elektrowni jądrowej położonej na sztucznej wyspie - zaczął narastać negatywny stosunek społeczeństwa do tego typu elektrowni (Mynatt, 1982). Na początku lat osiemdziesiątych XX w., na fali obaw przed ewentualną wojną oraz licznych demonstracji nakierowanych przeciwko energetyce jądrowej kojarzonej ze zbrojnym konfliktem nuklearnym, wygenerowany został negatywny stosunek społeczny do budowy elektrowni jądrowych. Kolejnym czynnikiem negatywnie wpływającym na stosunek społeczeństwa amerykańskiego do energetyki jądrowej była awaria jednostki w Czarnobylu. Ten stan świadomości zdominował wówczas myślenie Amerykanów o energetyce jądrowej. Zmianę w poglądach społeczeństwa amerykańskiego przyniosła końcówka lat osiemdziesiątych, kiedy to pod wpływem trudności na rynku ropy naftowej oraz pojawiających się informacji o globalnym ocieplaniu się klimatu, nastąpił znaczący wzrost poparcia dla budowy nowych i funkcjonowania istniejących elektrowni jądrowych. Ta tendencja ugruntowała się w latach dziewięćdziesiątych, zmieniając jednoznacznie stosunek do tego źródła energii (Misiak i Łucki, 2010).

Stosunek społeczeństwa polskiego do energetyki jądrowej obecnie rozpatrywany jest w perspektywie transformacji energetycznej kraju. Wdrażane w jej ramach zmiany dotyczące wytwarzania i korzystania z energii w celu ograniczenia emisji gazów cieplarnianych są wynikiem polityki klimatycznej Unii Europejskiej. Zasadniczo odnosi się ona nie tylko do sektora energetycznego, ale do całej gospodarki, a szerzej - nawet społeczeństwa i kultury. W praktyce podstawowym działaniem jest tu dekarbonizacja, oznaczająca rezygnację z wykorzystywania do produkcji energii elektrycznej paliw kopalnych. Dla Polski, której zasadniczym zasobem i źródłem energii jest węgiel, oznacza to istotne przeobrażenia nie tylko w energetyce, ale również 
w szeroko rozumianej sferze gospodarczo-społecznej. Tak zwana zeroemisyjna gospodarka, w wymiarze energetycznym, ma się opierać na odnawialnych źródłach energii (OZE), wykorzystaniu elektrowni wiatrowych, wodnych, biogazowni, ogniw fotowoltaicznych oraz elektrowni jądrowych. Istotne jest, że obecnie Polska nie posiada elektrowni jądrowych, przy czym planowana jest budowa przynajmniej dwóch (pierwsza ma powstać do roku 2033). Zgodnie z założeniami Ministerstwa Klimatu i Środowiska (2021) udział elektrowni jądrowych w produkcji energii elektrycznej szacowany jest na 20-25\% dla pierwszej połowy lat czterdziestych obecnego wieku. Konkretnym przykładem stosunku społeczeństwa polskiego do procesów transformacji energetycznej, traktowanych jako proces dekarbonizacji i zmniejszającej się roli węgla jako źródła energii w polskiej gospodarce, może być jej społeczna percepcja z perspektywy Górnego Śląska - największego zagłębia węglowego w Europie, opisana przez Piotra Żuka, Pawła Żuka i Przemysława Plucińskiego (2021). Autorzy, z uwzględnieniem aktualnej sytuacji pandemicznej, na reprezentatywnej próbie społeczeństwa polskiego wskazują polityczne i ideologiczne podłoże konfliktu toczącego się wokół problemu dekarbonizacji. Na tle ogólnej zgody co do kierunku przekształceń sektora energetycznego w stronę produkcji czystej energii zarysowuje się wyraźny podział na zwolenników i przeciwników tak rozumianych zmian, zgodny z ich preferencjami politycznymi. „Transformacji energetycznej i żądań ekologicznych najbardziej sprzyjają ugrupowania lewicowe i liberalne. Mieszkańcy dużych miast, a także ludzie lepiej wykształceni i mniej religijni są bardziej otwarci na transformację energetyczną” (Żuk, Żuk i Pluciński, 2021: 1).

\section{Priorytety transformacji energetycznej w świadomości społeczeństwa polskiego}

Opisując transformację energetyczną Polski, której zasadniczym celem jest ograniczenie emisji gazów cieplarnianych, z perspektywy świadomości społecznej, warto przyjrzeć się temu, na co zwracają uwagę Polacy, myśląc o zmianach dotyczących wytwarzania energii i korzystania z niej. Na podstawie ogólnopolskich badań reprezentatywnych przeprowadzonych przez CBOS możemy odtworzyć hierarchię czynników istotnych dla społeczeństwa polskiego w perspektywie wprowadzanej transformacji energetycznej (Roguska, 2021). Zdaniem Polaków najważniejszym czynnikiem, który należy brać pod uwagę, dokonując transformacji energetycznej kraju, jest cena energii i jej koszt dla obywateli (51\% wskazań). Zasadniczy motyw 
zmian dotyczących wytwarzania energii i korzystania z niej, tj. korzyści dla środowiska naturalnego, zajmuje dopiero drugą pozycję w hierarchii ważności (43\% wskazań). Można to uznać za przejaw obaw społeczeństwa polskiego dotyczących zwiększenia się sfery ubóstwa energetycznego, jako niepożądanego skutku transformacji energetycznej. Na trzeciej pozycji pod względem ważności uplasowała się kwestia bezpieczeństwa energetycznego. Zbliżone pod względem liczby wskazań notowania uzyskały: zapewnienie ciągłości dostaw energii (29\%), bezpieczeństwo technologii produkcji energii (27\%) oraz korzystanie z krajowych źródeł energii (27\%). Jako potrzebę bezpieczeństwa energetycznego kraju można też interpretować wskazania na konieczność dywersyfikacji wykorzystywanych źródeł energii (24\%). Kolejnymi wysoko notowanymi przez Polaków elementami transformacji energetycznej, które jednocześnie są ważne jako wpływające na zjawisko ubóstwa energetycznego, były czynniki technologiczne oraz społeczne: zwiększenie efektywności wykorzystania energii, czyli zmniejszenie energochłonności gospodarki i zmniejszenie zużycia energii (24\%) oraz udział obywateli w produkcji energii elektrycznej i cieplnej, a także skutki zmian dla górników (łącznie 23\%). Warto podkreślić, że Polacy, myśląc o transformacji energetycznej, której celem jest ograniczenie emisji gazów cieplarnianych, w niewielkim stopniu biorą pod uwagę kwestie polityki Unii Europejskiej i zobowiązań międzynarodowych. Te kwestie wprawdzie zostały przez nich uwzględnione, ale uzyskały najmniejszą (12\%) liczbę wskazań (Roguska, 2021).

\section{Energetyka jądrowa, rola i znaczenie źródeł energii elektrycznej - sposoby myślenia o przyszłości energetyki w Polsce}

Analizując źródła energii elektrycznej w Polsce, należy zauważyć, że obecnie najważniejszym z nich jest węgiel. Wprawdzie jego udział maleje, ale nadal więcej niż dwie trzecie energii elektrycznej produkowane jest $\mathrm{z}$ węgla. Z danych Ministerstwa Klimatu i Środowiska wynika, że łącznie jedna trzecia energii elektrycznej pochodzi z OZE i gazu (odpowiednio 18\% i 10\% oraz dodatkowo 2\% z tzw. innych źródeł energii) (Ministerstwo Klimatu i Środowiska, 2021). Transformacja energetyczna zawierająca dekarbonizację ma doprowadzić do zasadniczej zmiany roli i znaczenia różnych źródeł wykorzystywanych do produkcji energii elektrycznej. Zakłada się, że w przyszłości wzrośnie znaczenie odnawialnych źródeł energii i wykorzystywana będzie energetyka jądrowa. W myśl założeń przyjętej przez Unię 
Europejską polityki klimatycznej wycofane mają być źródła energii związane z wytwarzaniem dwutlenku węgla. Niepożądanym źródłem energii elektrycznej będzie zatem nie tylko węgiel, ale także ropa naftowa, drewno i gaz. Analizując transformację energetyczną w Polsce w perspektywie świadomości społecznej, warto przyjrzeć się sposobom myślenia i opiniom społeczeństwa polskiego dotyczącym różnych źródeł energii, a więc temu, które z nich Polacy traktują jako istotne źródła energii elektrycznej na przyszłość. Na podstawie ogólnopolskich badań realizowanych przez CBOS (Roguska, 2021) można dokonać analizy wizji przyszłości, jaka rysuje się w świadomości społeczeństwa polskiego. Polacy poproszeni o określenie, jaki procent energii elektrycznej powinien być wytwarzany z poszczególnych źródeł w przyszłości (w latach 2035 i 2050), wskazali na zasadnicze tendencje znaczącego spadku energii produkowanej z węgla oraz istotny wzrost jej produkcji z OZE. Jednocześnie respondenci nie przewidują zupełnego wyeliminowania węgla z produkcji energii elektrycznej. Choć OZE mają generować prawie połowę energii elektrycznej, to węgiel postrzegany jest jako ważny element miksu energetycznego w przyszłości. Co istotne, nawet w dalszej perspektywie czasowej, zdaniem Polaków, będzie odgrywał większą rolę niż energia atomowa, to zaś można interpretować jako znaczny poziom nieufności wobec energii jądrowej. W społecznej percepcji atom jako źródło energii jest postrzegany gorzej niż węgiel. Ma to tym większe znaczenie, że powszechnie znane są negatywne konsekwencje wykorzystywania energii z węgla (Herudziński i in., 2019).

Przyglądając się społecznej percepcji źródeł energii elektrycznej, zwłaszcza energetyce jądrowej, w odniesieniu do przyszłości, dostrzec można różne sposoby myślenia wynikające ze społeczno-demograficznych cech badanych. Węgiel jako źródło energii szczególnie negatywnie postrzegany jest przez: osoby młode, zamożne, wyżej wykształcone, mieszkające w dużych miastach. Te kategorie społeczne minimalizują też jego znaczenie jako źródła energii w przyszłości. Podobnie, w aspekcie cech społeczno-demograficznych respondentów, postrzegany jest gaz - większe znaczenie na przyszłość przypisują mu ludzie gorzej wykształceni, mniej zamożni, starsi i mieszkańcy wsi. Wzrost znaczenia odnawialnych źródeł energii zdaje się budzić najmniejsze emocje. Przyszłość energetyczną Polski wiążą z nimi głównie ludzie młodzi, lepiej wykształceni, zamożni i mieszkańcy największych miast, ale także kobiety, osoby w średnim wieku, posiadający wykształcenie średnie i mieszkańcy małych oraz średnich miejscowości. Najbardziej kontrowersyjnym źródłem energii zdaje się być atom. Rozwój energetyki jądrowej częściej niż przeciętnie popierany jest przez młodych, mężczyzn, zamożnych i mieszkańców największych miast. 
Tabela 1. Poparcie dla idei budowy elektrowni jądrowych w Polsce (w \%)

\begin{tabular}{|c|c|c|c|c|c|c|c|c|c|}
\hline $\begin{array}{c}\text { Odpowiedzi } \\
\text { respondentów }\end{array}$ & $\mathbf{1 9 8 7}$ & $\mathbf{1 9 8 9}$ & $\mathbf{2 0 0 6}$ & $\mathbf{2 0 0 8}$ & $\mathbf{2 0 1 1}$ & $\mathbf{2 0 1 3}$ & $\mathbf{2 0 1 6}$ & $\mathbf{2 0 1 8}$ & $\mathbf{2 0 2 1}$ \\
\hline $\begin{array}{c}\text { Opowiadał(a)bym się } \\
\text { za budową }\end{array}$ & 30 & 20 & 25 & 38 & 40 & 35 & 38 & 34 & 39 \\
\hline $\begin{array}{c}\text { Sprzeciwiał(a)bym się } \\
\text { budowie }\end{array}$ & 39 & 46 & 58 & 45 & 53 & 52 & 50 & 50 & 45 \\
\hline Trudno powiedzieć & 31 & 34 & 17 & 17 & 7 & 13 & 11 & 16 & 16 \\
\hline
\end{tabular}

Źródło: opracowanie własne na podstawie Roguska, 2021.

Omawiając społeczną percepcję energetyki jądrowej, należy zwrócić uwagę na społeczno-demograficzne cechy badanych, różnicujące sposoby myślenia społeczeństwa polskiego. Istotnie różnicującą poparcie dla energetyki jądrowej zmienną jest płeć - mężczyźni (55\%) okazują się większymi jej zwolennikami niż kobiety (25\%). Więcej zwolenników budowy elektrowni jądrowych odnajdziemy też w kategoriach ludzi: młodych, posiadających wykształcenie wyższe, przedstawicieli kadry kierowniczej i specjalistów, ale również średniego personelu, prywatnych przedsiębiorców i robotników wykwalifikowanych, mieszkańców największych miast oraz osób zamożnych (osiągających dochody od 3 tys. na osobę w gospodarstwie domowym). Ponadto, w kontekście sygnalizowanego wcześniej zagadnienia konfliktów lokalnych na tle inwestycji energetycznych, warto wskazać, że problem ten znajduje odzwierciedlenie w wynikach badań ogólnopolskich. Zdecydowanie mniejszym poparciem społecznym cieszą się te inwestycje, które miałyby być zrealizowane w pobliżu miejsca zamieszkania badanego. W takim przypadku zdecydowanie przeważają przeciwnicy inwestycji, aż jedna trzecia badanych w takiej sytuacji staje się oponentami (tab. 2).

Tabela 2. Akceptacja sąsiedztwa elektrowni atomowej (w \%)

\begin{tabular}{|c|c|c|c|c|c|c|c|}
\hline $\begin{array}{c}\text { Odpowiedzi } \\
\text { respondentów }\end{array}$ & $\mathbf{2 0 0 6}$ & $\mathbf{2 0 0 8}$ & $\mathbf{2 0 0 9}$ & $\mathbf{2 0 1 0}$ & $\mathbf{2 0 1 1}$ & $\mathbf{2 0 1 3}$ & $\mathbf{2 0 2 1}$ \\
\hline $\begin{array}{c}\text { Opowiedział(a)bym się } \\
\text { za budową }\end{array}$ & 17 & 25 & 36 & 32 & 28 & 25 & 24 \\
\hline $\begin{array}{c}\text { Sprzeciwił(a)bym się } \\
\text { budowie }\end{array}$ & 72 & 63 & 56 & 57 & 67 & 70 & 64 \\
\hline $\begin{array}{c}\text { Nie potrafię zająć stano- } \\
\text { wiska }\end{array}$ & 11 & 12 & 8 & 11 & 5 & 5 & 12 \\
\hline
\end{tabular}

Źródło: opracowanie własne na podstawie Feliksiak, 2001. 
Należy podkreślić, że większość społeczeństwa polskiego postrzega energetykę jądrową jako niezbywalny aspekt transformacji energetycznej, której fundamentem jest proces dekarbonizacji - rezygnacji z węgla jako najważniejszego źródła energii elektrycznej w Polsce, chociaż różnice nie są znaczące $-44 \%$ za, a $37 \%$ przeciw temu procesowi. Reasumując, Polacy, akceptując założenia transformacji energetycznej i opowiadając się za rezygnacją z węgla jako głównego źródła energii, w większości są za wykorzystywaniem energii jądrowej. Jednocześnie, choć w zmniejszającym się stopniu, nadal opowiadają się przeciw budowie elektrowni atomowych w Polsce. Niezmiennie większość Polaków nie chciałaby mieszkać w pobliżu elektrowni atomowej, ale wzrasta zaufanie w zakresie technologiczno-kompetencyjnym, dotyczącym potencjalnie wykorzystywanych do budowy elektrowni jądrowych technologii i kompetencji realizujących te inwestycje pracowników (Feliksiak, 2021).

\section{Podsumowanie}

Transformacja energetyczna jest zmianą wprowadzaną zgodnie z wcześniej przyjętymi planami. Bezpośrednio wynika ona z polityki Unii Europejskiej oraz poszczególnych rządów wdrażających konkretne rozwiązania dotyczące zmian w wytwarzaniu i korzystaniu z energii. W artykule przyjęto założenie, że warunkiem jej powodzenia jest przychylność społeczeństwa, którego zmiana ta będzie dotyczyła. Analizie poddane zostały opinie społeczeństwa polskiego, traktowane jako wyraz jego stosunku do planowanej transformacji energetycznej kraju. Uwagę zwrócono zwłaszcza na czynniki, które zdaniem Polaków będą szczególnie istotne w perspektywie wprowadzanych zmian.

Analizując czynniki ważne dla społeczeństwa polskiego w procesach transformacji energetycznej, należy podkreślić, że najważniejszym z nich jest czynnik ekonomiczny, czyli koszty transformacji energetycznej wyrażające się w ostatecznej cenie energii i możliwościach nabywczych Polaków. Transformacja energetyczna jest akceptowalna przez społeczeństwo, nawet jeśli związana będzie z fundamentalnymi zmianami polskiej energetyki i całej gospodarki polegającymi na jej dekarbonizacji, pod warunkiem że nie będzie narażała go na zjawisko ubóstwa energetycznego. Jest to czynnik priorytetowy zarówno dla ogółu badanych, jak i dla większości grup społeczno-demograficznych. Ponadto istotnym elementem transformacji w Polsce z perspektywy świadomości społecznej jest szeroko rozumiana kwestia bezpieczeństwa energetycznego. 
Wizje przyszłości dotyczące energetyki polskiej obecne w świadomości społeczeństwa dotyczą wzrostu znaczenia OZE, w tym energetyki jądrowej. To one w opinii Polaków powinny być głównym źródłem energii elektrycznej. Zarysowuje się też niejednoznaczny stosunek społeczeństwa do rozwoju energetyki jądrowej w Polsce. Obawy dotyczące energii pozyskiwanej z atomu zdają się być większe niż strach przed szkodliwym wpływem wykorzystywania węgla, jako nieatrakcyjnego, ale znanego już dobrze źródła energii. W tym aspekcie - niedalekiej przyszłości - zdają się również zarysowywać rozbieżności pomiędzy planowaną transformacją energetyczną a opiniami Polaków. Dotyczą one także konwencjonalnych źródeł energii: węgla i gazu, które w społecznym przekonaniu nadal będą odgrywały istotną rolę, obok energii pozyskiwanej z atomu jako stabilnego źródła energii - wzbudzającego największe nadzieje na uzyskanie bezpieczeństwa energetycznego kraju, ale jednocześnie większe obawy niż pozostałe źródła energii.

\section{Literatura}

Adamowicz, M. (2021). Zielona gospodarka, zielony wzrost i zazielenienie jako formy realizacji koncepcji zrównoważonego rozwoju. Wieś i Rolnictwo, 2(191), 13-33.

Dunlop, R., Catton, W. (1979). Environmental sociology. Annual Review of Sociology, 5, 243-273.

Feliksiak M. (2021). Stosunek do energetyki jądrowej. CBOS. Komunikat z badań, 69, 1-8.

Giddens, A. (2010). Katastrofa klimatyczna. Warszawa: Prószyński i S-ka.

Herudziński, T., Boguszewski, R., Owczarek, D., Bondyra, K. (2019). Ubóstwo energetyczne w obliczu regulacji przeciwdziałajq̨cych zanieczyszczeniu powietrza. Warszawa: Wydawnictwo SGGW.

Jezierski, G. (2014). Energia jq̨drowa wczoraj i dziś. Warszawa: Wydawnictwo WNT.

Misiak, W., Łucki, Z. (2010). Energetyka a społeczeństwo. Aspekty socjologiczne. Warszawa: Wydawnictwo Naukowe PWN.

Ministerstwo Klimatu i Środowiska (2021). Polityka Energetyczna Polski do 2040 r. Streszczenie, https://www.gov.pl/attachment/c5d4a303-2a45-4225-b84d-d6ad12f7c1c1 (dostęp: 30.11.2021).

Matczak, P. (2000). Problemy ekologiczne jako problemy społeczne. Poznań: Wydawnictwo Naukowe UAM.

Mynatt, F.R. (1982). Nuclear reactor safety research since Three Mile Island. Science, 216, 131-135.

Olkuski, T. (2018). Światowe zużycie energii pierwotnej oraz zapotrzebowanie na nią w przyszłości. Polityka i Społeczeństwo, 16(2), 56-70.

Owczarek, D., Miazga, A. (2015). Ubóstwo energetyczne w Polsce - definicja i charakterystyka społeczna grupy. Warszawa: Fundacja Instytut na rzecz Ekorozwoju. 
Popkiewicz, M. (2016). Rewolucja energetyczna. Ale po co? Katowice: Wydawnictwo Sonia Draga.

Roguska, B. (2021). Transformacja energetyczna - oczekiwania i postulaty. CBOS. Komunikat z badań, 70, 1-16.

Swacha, P., Novikova, K. (2019). Ubóstwo energetyczne a proces przekształceń sektora energetycznego Polski (na tle państw europejskich). W: T. Herudziński, J. Wojnicki (red.), Społeczności lokalne - samorzq̨dność i inicjatywy oddolne w globalnym świecie (ss. 141-154). Warszawa: Wydawnictwo SGGW.

Trempała, W. (2016). Geneza, rozwój i status socjologii środowiskowej. Studia Ecologiae et Bioethicae, 141, 165-197.

Wagner, A., Grobelski, T., Harembski, M. (2016). Is energy policy a public issue? Nuclear power in Poland and implications for energy transitions in Central and East Europe. Energy Research \& Social Science, 13, 158-169.

Zajączkowska, M. (2016). Bezpieczeństwo energetyczne (Unii Europejskiej). Studium teoretyczne. Krakowskie Studia Międzynarodowe, 3, 117-126.

Zawalińska, K., Kinnunen, J., Gradziuk, P., Celińska-Janowicz, D. (2020). To whom should we grant a power plant? Economic effects of investment in nuclear energy in Poland. Energies, 13(11), 2687.

Żuk, P., Żuk, P., Pluciński, P. (2021). Coal basin in Upper Silesia and energy transition in Poland in the context of pandemic: The socio-political diversity of preferences in energy and environmental policy. Resources Policy, 71, https://doi.org/10.1016/ j.resourpol.2021.101987.

Żuk, P., Żuk, P. (2021). Increasing energy prices as a stimulus for entrepreneurship in renewable energies: Ownership structure, company size and energy policy in companies in Poland. Energies, 14(18), https://doi.org/10.3390/en14185885. 